\title{
Artificial Intelligence: Implication on Management
}

\section{Koteswara Rao Ballamudi}

Solution Architect, Software Engineering Architecture Department, Cyber Global, Inc., USA

*Corresponding Contact:

Email: koteswarabv@gmail.com

Manuscript Received: 28 Sept 2019 - $\quad$ Revised: 15 Dec $2019 \quad$ - $\quad$ Accepted: 27 Dec 2019

\begin{abstract}
The advancement in Artificial Intelligence (AI) is surging and it is at the center of improved output. Consequent on the advancement in the science of AI, human-to-machine interactions is facilitated, business models and logics now vary, and the lifestyle as well as the living standards of humans has change. Artificial Intelligence (AI) is often regarded as a complex a unit. There are many description and numerous more impressions of what makes up Artificial Intelligence. The risk implications of Artificial Intelligence vary and it's dependent on the degree of its usage. The advantages of artificial intelligence out numbers the risks it conveys, particularly in the world of business usage and its application is resulting in a world that is innovative and smarter. With the expectation that professions will be impacted, it conveys immediate effect on firms, their workers and organizational management. The current study sought to answer some research questions; Are there knowledge about the effects of Artificial Intelligence on management? What is the current prediction for the future of management as it relate to emergence of Artificial Intelligence. Does current study specify the duties of middle managers in the future following the rise in AI? It adopted the systematic literature review approach where relevant literatures are selected and used for the analysis. Following Jesson, Matheson \& Lacey (2011) approach to systematic review to include; (a) Mapping the area through a scoping review, b) Detailed domain search, c) Quality appraisal, d) Data gathering e) Synthesis, and f) Report w riting, over 100 papers on the subject were selected. On screening, it was reduced to about 15 papers with direct relationship on the subject. The study found out that; AI is a necessary evil to and for the future of firms. It will have varying degrees of effect on management. AI technology will discharge managerial assignment and will be helpful in addressing management challenges. Managers and management therefore need get new competencies and skills to tap into new frontiers that are AI based.
\end{abstract}

Key Words: Artificial Intelligence, Management, Organization, Organizational Management 


\section{INTRODUCTION}

The emerging and novel science through internet of things (IoT), big data, data science, cloud computing, and artificial intelligence (AI), are introducing variations to manner and way we live, and work. Further improvement of these technologies would contribute to the creation of a more sophisticated automation with super connectivity (Schwab 2017; Bloem 2014; Klosters 2016; Park 2017). Basically, the advancement in Artificial Intelligence (AI) is the centre of improved output visible in all sector. Consequent on the advancement in the science of AI, human-to-machine interactions would be facilitated, business models and logics would vary, and the lifestyle as well as the living standards of humans will change. Artificial Intelligence (AI) is often regarded as a complex a unit. There are many description and numerous more impressions of what makes up Artificial Intelligence. The risk implications of Artificial Intelligence vary and it's dependent on the degree of its usage (Donepudi, 2014a). The advantages of artificial intelligence out numbers the risks it conveys, particularly in the world of business usage. The application of Artificial intelligence is resulting in a world that is innovative and smarter. It is already being applied in many areas including businesses and is expected to surge.

A look at history shows that the greatest changes in human existence are consequence on developments in technology. For instance; between 4500 and 3300 BCE saw the inventions of the wheel (Berman, 2017), and also the first Industrial Revolution that designed the water and steam power for machines for production purpose (Syam \& Sharma, 2018). Thereafter, the second industrial revolution emerged with electricity, telephone, plane and other automobile (Sentryo, 2017). Marr, (2016) opined that by the third industrial revolution, there was the emergence of electronics that herald the use of computers and automation. These dynamics influenced how people work. For instance, the use of steam and water power had a significant influenced on production. It increased production efficiency; hence made life and work easy for the employees (Huginn, et al., 2019; Donepudi, 2014b).

More so, other professions also felt the impact. For instance, the muscle power of animals and humans were substituted with the engine power. Consequently, some profession disappeared owing to changes in methods. Huginn, et al., (2019) opined that while some professions were lost there was an increased employment of artisans, and craftsmen in factories. At the present, the times are exceptional. Technological transformation is manifested in basically all area of our livings. The current industrial revolution "Fourth Industrial Revolution", is powered by communications technology, Internet of Things, digitization, machine learning, artificial intelligence (AI), autonomous vehicles and robotics, biotechnology, energy storage, nanotechnology and quantum computing (Schwab, 2016). Syam \& Sharma, (2018) opined that decision making will be the significant variation in the Fourth Industrial Revolution. Before now, humans were responsible for decisions, now automation and machines algorithms are responsible for decisions. Today, a lot of discussion and concerns has emerged following the jobs at the risk of exposure to technological development, including AI consequence on the increased use of automation will surged. Automation here implies artificial intelligence, use of engines or other machines sequenced by algorithms. The intention of such automation is to perform certain task by humans (Porsteinsson, 2017). In 2013, Oxford University opined that about $47 \%$ of jobs in the United State labor market were at risk of artificial intelligence (Frey \& Osborne, 2013).

Specifically, Some task has been identified as those on risk Among to include the task of the credit accountants, civil engineering technicians and auditors, credit analysts, legal assistants, human resource assistants loan officers, market research analysts, marketing specialists, 
revenue agents, and tax examiners. The forecasts here mentioned with regards to the impact of technological advancement on job markets are already manifested in manifolds. For instance, in 2015, a Japanese Firm known as Fukoku Mutual Life Insurance, substituted over 34 workers with the Artificial intelligence by IBM's Watson whose task were to estimate clients payout. According to the firm, the mobe was to increase profitability and make saving $\mathrm{s}$ to the tune of, $140 \mathrm{~m}$ yen $(£ 1 \mathrm{~m})$ within one year and $200 \mathrm{~m}$ yen $(£ 1.4 \mathrm{~m})$ in the second years (McCurry, 2017).

A forecast by Goldman Sachs Group Inc. has indicated an expected surge in the US productivity consequence on the use of Artificial Intelligence by 2025. By the second quarter, about $13 \%$ of S\&P 500 companies have opined that their decision to use artificial intelligence has increased their venture capital funding to an amount $\$ 10$ billion within a year (Syam \& Sharma, 2018). Gartner, an Information Technology research firm estimates that Artificial Intelligence and machine learning would also increase jobs. There are some jobs that are driven by these emerging technologies. Syam \& Sharma, (2018) puts the number of such jobs to reach excess of million new by 2025 .

Baldur Arnarson, (2017) reported an increased in artificial intelligence and a reduction in the number of available in the banking sector, hence the decrease in the labour by over 2000 . According to Ómar Óskarsson, (2019), a report published by the Icelandic Prime Minister's on the Fourth Industrial Revolution expressed concerned on the level of job loss which the application of artificial intelligence will cause. Ómar Óskarsson, (2019) opined that industry, service and sales jobs were most likely to be automated. Huginn, et al., (2019) reported that the significant (about 60\%) of those employed in the Icelandic labor market undertake task that are deemed to be slightly or most likely to be automated the near future. Thi imply that a country such as Iceland stood a greater risk of being replaced by machines in the days ahead. Huginn, et al., (2019) furthered that tough jobs may not be totally substituted; it was likely to vary considerably. For instance, $90 \%$ of the task performed by technical and the specialized employees are deemed to be moderately likely to be substituted (Huginn, et al., 2019). These jobs include carpentery, bankers, blacksmithing, bakers and other task requiring specialized education or knowledge. In the literature, general forecast and predictions concerning the impact of automatization on the job market has been documented, few or none of these study has come out strongly with numbers on impact artificial intelligence emergence will have on the future employment of middle managers (Frey \& Osborne, 2013; Donepudi, 2017). Certain frameworks which are used in literature to explain the composition of the job that will disappear consequence on AI seem lacking in its explanations.

Frey \& Osborne, (2013) defined middle-level managers as workers whose position in organization's hierarchy is the middle and their roles is to get work done through their assistants, manage people and resources, plan for the days ahead, influence company's decision in and outside the firm and periodically adjust the objectives of the team to suit the goal of the company (Rezvani, 2017). According to Kolbjørnsrud, Amico and Thomas (2015) Artificial Intelligence will impact all levels of management, starting from the low to the toplevel management. Their report suggested that the role of managers may be eroded in the near future. For this reason, there is the need to understand the effects of Artificial Intelligence on management. This is the overall objective of this study. For this reason, the study possess the following questions; are there knowledge about the effects of Artificial Intelligence on management? What is the current prediction for the future of management as it relate to emergence of Artificial Intelligence. Does current study specify the duties of middle managers in the future following the rise in AI? 


\section{Objectives of this study}

- To increase knowledge of AI, its opportunities and issues within organizations.

- To outline the role of AI technology in management.

- Identify the need for managers in preparation for the changing labour market

- Emphasize the importance of acquiring AI knowledge for competition in the marketplace.

This study will address and close this research gap. Issues on how the emergence of Artificial intelligence would disrupt business are discussed. It creates awareness on the need for actions driven decision for firms adopting $\mathrm{AI}$ and contributes immensely to the artificial intelligence theory. The rest of the study is arranged as follows. Literature review is done in section 2. Methodology is done section 3. Section 4 handles analysis and result. Discussion of result is done in section four. Finally, conclusion and recommendation is done in chapter 5.

\section{REVIEW OF THE LITERATURE}

\section{Management and managers' role in organizations}

The term management is an essential vehicle used by organization to achieve organizational objectives. Jones, (2013) opined that just as managers, management is responsible for the coordination of human and capital resources and ensuring that firms' goals are realized. Managing the organizational culture, planning and directing the work environment of the organization is the duty of the manager. For instance, the manager consistently scouts for new markets and products, finding solutions to technical issues and breaks down the goals into simple and achievable units (Jones, 2013). However, in other that the five main function of management which include; planning, organizing, controlling, commanding and coordinating as opined by Fayol, (1949) be effectively performed, firms' position managers across different stratum and saddle them with various degrees of skills, authority and responsibility (Rezvani, 2017). In the first instance, they are ordered by hierarchy and each hierarchy commands certain level of authority. The lower level takes instruction from the middle level while the middle level in turn answers to the top level management (Jones \& George, 2015). They are now positioned into various departments according to knowledge and skill (Jones \& George, 2015; Donepudi, 2018).

The team of managers and the workers are simplified by their functions. They operate together because they have comparable knowledge and skills to perform assigned task and work (Jones \& George, 2015). The top managers are top management; those that occupy the apex and this include the CFOs or CEOs (Kolbjørnsrud et al., 2015). The CEO is responsible for maximizing the profit and production of the firm by investing shareholder funds and assets in viable projects (Jones, 2013). They themselves design the organizational objectives, and determine the functions, and monitor the duties of the middle managers (Jones \& George, 2015). The middle-level managers are employees who are placed at the middle hierarchical level. They are the managers of mini projects, office managers, supervisors, and departmental managers (Kolbjørnsrud et al., 2015). The make sure that available job is done through their assistants, they manage projects by using people and employees in the company, forecast the future and make resources available for future task, constantly seek for the nest way to organize employees to gain optimum resource usage and influence decisions inside and outside the firm, and vary the objectives of the team to achieve company goals (Rezvani, 2017).

Front-line managers are those positioned at the lowest hierarchical order of the organization. These ones are involved in all organizational processes as the oversee the non-managerial 
employees to carry out assignment that are required to produce goods or discharge services (Jones \& George, 2015). Otherwise known as the low level managers, they include managers of smaller projects, office managers, shift supervisors, and departmental managers (Kolbjørnsrud et al., 2015). The higher the managerial, the more the time devoted to organizing and planning resources to surge the organizational performance. Similarly, the lower the hierarchical level of the manager, the more time he devotes controlling and directing the employees (Jones \& George, 2015). Each firms department has all 3 kinds of managers, where top managers devote most of their time planning and organizing while the controlling and directing is done by the is middle and low class managers. Majorly, the significant role of the manager includes the act of decision-making.

\section{Technological Development and Artificial Intelligence}

Organizations exist in complex and dynamic environment with observable and continuous variation. Noticeable changes include those with regards to operations, firms' structure and best ways of management. Nevertheless, automation and technological development is playing an important role and has shaped the function of management (Copra, 2018). In management literature, technology is described all combination of inputs including of machines, computers, skills, knowledge and information which managers adopt in the production of goods and services (Jones \& George, 2015). Technological changes produce technological forces, with a tremendous increase in technology that has left dramatic impacts to the business sector.

Most likely the most celebrated and narrated events today is the concept of artificial intelligence (AI), which on the whole is described as an area in computer science particularly of information Technological system that can perform, learn, understand and sense (Kolbjørnsrud et al., 2015). To be specific, AI consist machine learning; the capability of machines to enhance performance without directives or command from humans (Antonescu, 2018). The impact of AI emergence on businesses is not consequence on its direct benefits but also the inspirations it offers for new innovations. The result of these innovations being new products in form of artificial vision natural language processing, audio/speech recognition, and robotics and many other possibilities (Antonescu, 2018). Statista a data analysis company has put global estimated earnings from application of Artificial Intelligence to rise to over 30,000 million dollars by 2025 (Columbus, 2018).

Technology and Artificial intelligence has granted biggest the opportunities to cut labor costs. According to Oxford's research an estimated $47 \%$ of jobs across the US labor stood the risk of machine learning and AI driven automation. However, the forecast was that jobs that will be substituted are those which at the moment incorporate Artificial Intelligence and machine learning (Frey \& Osborne, 2013). Syam \& Sharma, (2018) puts the number of jobs lost by 2025 at two million. There are numerous ways in which Artificial Intelligence is changing profession and job dynamics. Intelligent machines are sequencing and computers programmes with AI built that linked multiple automation, processes and people (Kolbjørnsrud et al., 2015). Owing to the application, these systems are more accurate and dynamic than algorithmic sequencing and can effectively adapt to current environments with the understanding of user's language and the capability to interact with them. These technology and capabilities have made them the absolute expert (Farajpour \& Zerehnazi, 2013).

Now Artificial Intelligence technologies have taken over numerous fields, introducing efficiency- and accurate driven sequence and decisions in all sectors starting from the automotive industry to health care and finance (Manaila, 2019). AI is used in self driven 
vehicles, it can identify road signs, outline trading signals, financial irregularities, diagnose ailments including cancers etc. (Ateniese, 2019). Though Artificial Intelligence brings about business opportunities, challenges still exist of which Stevens (2019) pointed out to include security and privacy. The work by Steven and other studies on the subject shows these machines can be deceived, hacked or jeopardized. Ateniese, (2019) opined that this is a great concern for firms who adopts artificial intelligence because when data are leaked, and then it becomes a serious issue.

\section{Artificial intelligence and management in organizations}

The emergence of Artificial Intelligence will have a significant effect the management and the future eof the organizations. Consequently, there is an increase in interest by analyst in this area. Management literature describes artificial intelligence as the use of artificial and machine learning languages or any other embedded programmes in managerial, administrative, problem solving and organizational level for the singular objective of making decisions either at the high, middle and low level management (Shim \& Rice, 1988). Literature in the field of management has forecasted the implementation of Artificial Intelligence will assist in the efficient and effective management of firm, assisting to improve their performance, profit, and revenue. Furthermore, breakthroughs in Artificial Intelligence are expected to greatly reform the place of work (Chopra, 2018).

As earlier explained, top managers devote most of their energy and resources planning and in organizing while the middle- and low-level counterparts devote more time leading and controlling. In a survey conducted by Accenture Institute for High Performance and Accenture Strategy, where over 1770 managers were selected from the high, middle and low level to take part in the study. Result showed that Artificial Intelligence and computer systems could likely substitute managers responsibility of controlling, collaborating, coordinating, and problem solving. The study showed that managers were likely to be engaged on innovation, strategy formulation, and on the human inputs and resources within the organization (Kolbjørnsrud, et al., 2015). Before the end of this decade, AI will enter businesses on an extreme scale. Hence, unlike earlier waves of new technology that have disrupted blue collar and service jobs on a large scale, recent advancements in AI will change all levels of management (Kolbjørnsrud et al., 2015). AI will automate scheduling, reporting and resource allocation, along with taking time-consuming and administrative tasks off managers' shoulders (Kolbjørnsrud et al., 2015). Furthermore, AI-assisted analytics, hypothesis testing and simulation can be extremely effective for strategic decision-making and innovation throughout an enterprise (Kolbjørnsrud et al., 2015).

Although Artificial Intelligence opportunities which will create value, it also presents daunting challenges for executives and managers which will make them reconsider their task and re-evaluate the principles of their operation (Kolbjørnsrud et al., 2015). There will be an increase in Collaboration among machines and humans, while the division of labor wills vary (Kolbjørnsrud et al., 2015). Firms will have to re-strategies their operations, trainings and manner of talent acquisition to strategically fill roles that rely on human skills and judgment. As a result, managers will be kept on their toes to consistently seek new ways of evolving (Chopra, 2018). Conclusively, Artificial Intelligence will in general vary the levels of management, where certain roles of manager's including controlling, coordinating, collaborating and issues solving are most likely to be made mechanically. More so, reporting, scheduling, resource allocation and other administrative assignments will all be automated hence; managers will have enough time to innovate and strategies with other humans in the organization. 


\section{Methodology}

The current study adopts the systematic literature review approach. Relevant literatures are selected and used for the analysis. Jesson, Matheson \& Lacey (2011) proposed about six approach and steps as follows (a) Mapping the area through a scoping review, b) Detailed domain search, c) Quality appraisal, d) Data gathering e) Synthesis, and f) Report writing. Systematic review has been designed in the past decade and currently, the play a significant role in driving evidence-based decision. Systematic literature reviews outlines and assist in major scientific contribution to a subject, discussion and topic at hand, hence; and it is a vital methodology for making conclusions (Tranfield, Denyer, \& Smart, 2003). The process began by designing research questions of interest; with the identification of inclusion (journal papers on AI and management) and exclusion (Papers on AI but not bothering on the subject). The year and country in which the study was conducted are also noted. Key words like "management", "middle level managers", and "Artificial intelligence" were used to drive the search. A total of 150 published journals were gathered at first search. After a thorough review of abstract, literature review, methodology and result of these papers, about 50 were selected. It was further reduced to 20 journal paper upon subsequent screening. The 15 journal papers with direct relationship with the subject were then used for the analysis.

\section{ANALYSIS AND RESULT}

\section{Descriptive Analysis}

The 20 published journals cover various aspects of management and artificial. A breakdown of journals shows that studies from the US formed the bulk of the gathered paper, with $40 \%$ of studies focusing on American scenarios. The UK followed as the second largest proportion with about $20 \%$. The remainder of the proportions is as follows: India (10\%), Croatia (5\%), Romania (5\%), Iran (5\%) and Canada (5\%). Primarily, the studies all focused on secondary data analysis. Other occurring methodologies included literature reviews, experiments, and interviews, qualitative and quantitative based surveys.

\section{Artificial intelligence in Management}

About ten (10) papers that that borders on Artificial Intelligence and management, in following table, the papers objectives, methods and the main findings are outlined.

\begin{tabular}{|l|l|l|l|}
\hline $\begin{array}{l}\text { Author(s) } \\
\text { /Years }\end{array}$ & Study Objectives & Method & Major Result \\
\hline $\begin{array}{l}\text { Carr, et al. } \\
\mathbf{( 1 9 8 9 )}\end{array}$ & $\begin{array}{l}\text { To examine the factors } \\
\text { that are needed to } \\
\text { implement technological } \\
\text { variations in firms. }\end{array}$ & $\begin{array}{l}\text { Secondary } \\
\text { data analysis }\end{array}$ & $\begin{array}{l}\text { Champions will be required to } \\
\text { implement the variation of the } \\
\text { emerging AI science to firm }\end{array}$ \\
\hline $\begin{array}{l}\text { Karen S. } \\
\text { Jones }\end{array}$ & $\begin{array}{l}\text { To outline the scope of } \\
\text { artificial intelligence in } \\
\text { information and } \\
\text { management and }\end{array}$ & $\begin{array}{l}\text { Pundits } \\
\text { opinion and } \\
\text { Secondary } \\
\text { data analysis }\end{array}$ & $\begin{array}{l}\text { There is an essential role for } \\
\text { particular applications of } \\
\text { Artificial Intelligence in } \\
\text { information and management. } \\
\text { For instance AIderived technology }\end{array}$ \\
\hline $\begin{array}{l}\text { Koch, et } \\
\text { al. (2001) }\end{array}$ & $\begin{array}{l}\text { To adopt a software tool } \\
\text { that utilize only Intelligent } \\
\text { Autonomous product, that } \\
\text { is integrated with the } \\
\text { simple network }\end{array}$ & $\begin{array}{l}\text { Secondary } \\
\text { data analysis } \\
\text { of Autonomous Agents for } \\
\text { Network Management. For } \\
\text { today, the possibilities are }\end{array}$ \\
\hline
\end{tabular}




\begin{tabular}{|c|c|c|c|}
\hline & $\begin{array}{ll}\text { management } & \text { protocol } \\
(\mathrm{SNMP}) & \end{array}$ & & $\begin{array}{l}\text { endless but however, there are } \\
\text { more grounds to explore }\end{array}$ \\
\hline $\begin{array}{l}\text { Farajpour } \\
\text { and } \\
\text { Zerehnazi } \\
(2013)\end{array}$ & $\begin{array}{l}\text { To suggest and define the } \\
\text { use of expert systems in } \\
\text { management }\end{array}$ & $\begin{array}{l}\text { Secondary } \\
\text { data } \\
\text { Analysis }\end{array}$ & $\begin{array}{l}\text { Adopting AI ensures that } \\
\text { companies take advantage in } \\
\text { the areas of management } \\
\text { including strategic planning, } \\
\text { quality control and } \\
\text { management, production and } \\
\text { financial management }\end{array}$ \\
\hline $\begin{array}{l}\text { Ko and } \\
\text { C-H } \\
(2015)\end{array}$ & $\begin{array}{l}\text { To ensure managerial } \\
\text { effectiveness through the } \\
\text { integration of artificial } \\
\text { intelligence }\end{array}$ & Experiment & $\begin{array}{l}\text { Integration of AI can be } \\
\text { efficiently used in a practical } \\
\text { environment. The AI based } \\
\text { method can improve } \\
\text { managerial effectiveness; data } \\
\text { transfer, data quality, and } \\
\text { reduce service process time. }\end{array}$ \\
\hline $\begin{array}{l}\text { Calvin, et } \\
\text { al. (2017) }\end{array}$ & $\begin{array}{l}\text { To examine various skill } \\
\text { which can be combines } \\
\text { with AI management } \\
\text { structure }\end{array}$ & $\begin{array}{l}\text { Secondary } \\
\text { data analysis }\end{array}$ & $\begin{array}{l}\text { Management would benefit } \\
\text { from new knowledge for } \\
\text { business. Business should see it } \\
\text { as transformative tools }\end{array}$ \\
\hline $\begin{array}{l}\text { Miyan } \\
(2017)\end{array}$ & $\begin{array}{l}\text { To propose a general } \\
\text { insight on AI data mining } \\
\text { primary data mining } \\
\text { techniques identifying the } \\
\text { key fields to applied the } \\
\text { technique. }\end{array}$ & $\begin{array}{l}\text { Survey and } \\
\text { Secondary } \\
\text { data analysis }\end{array}$ & $\begin{array}{l}\text { Data Analysis that adopts } \\
\text { machine learning can assist in } \\
\text { enhancing decision-making } \\
\text { and experience of customers. } \\
\text { Banks, architects, and } \\
\text { customers all stand to benefit } \\
\text { from AI. Client segmentation, } \\
\text { profitability and marketing, } \\
\text { risk management, customer } \\
\text { relations, and fraud detection } \\
\text { are other benefits of AI }\end{array}$ \\
\hline $\begin{array}{l}\text { Hirsch } \\
\text { (2018) }\end{array}$ & $\begin{array}{l}\text { To evaluate how this fast } \\
\text { growing field of analysis } \\
\text { might be applied in the } \\
\text { field of risk management }\end{array}$ & $\begin{array}{l}\text { Secondary } \\
\text { data analysis }\end{array}$ & $\begin{array}{l}\text { Business managers will need to } \\
\text { enhance their skills to derive a } \\
\text { deeper understanding of AI } \\
\text { and how they will ensure that } \\
\text { the businesses upgrade and } \\
\text { compete favorably. } \\
\text { Inexperienced firms that are } \\
\text { without AI could affect their } \\
\text { competition ability. }\end{array}$ \\
\hline $\begin{array}{l}\text { Kiron } \\
\text { and } \\
\text { Spindel } \\
(2019)\end{array}$ & $\begin{array}{l}\text { To case study IBM talent } \\
\text { and performance } \\
\text { management }\end{array}$ & $\begin{array}{l}\text { Qualitative } \\
\text { analysis } \\
\text { Interviews }\end{array}$ & $\begin{array}{l}\text { IBM's efforts to effect } \\
\text { contemporary management are } \\
\text { part of AI process. Expectations } \\
\text { are continuously being aligned } \\
\text { on growth and skill growth in } \\
\text { IBM. Its certain they need to re- } \\
\text { skill-at scale machine. }\end{array}$ \\
\hline
\end{tabular}

Source: Field Survey, 2020 


\section{Human Labor Substitution by Artificial Intelligence}

\begin{tabular}{|c|c|c|c|}
\hline $\begin{array}{l}\text { Authors/ } \\
\text { Years }\end{array}$ & Study Objectives & Methods & Main Results \\
\hline $\begin{array}{l}\text { Britton, et } \\
\text { al. } 2017\end{array}$ & $\begin{array}{l}\text { To examine AI effect } \\
\text { within asset } \\
\text { management industry }\end{array}$ & $\begin{array}{l}\text { Qualitative } \\
\text { Interviews }\end{array}$ & $\begin{array}{l}\text { In the asset management sector; } \\
\text { current entry level workers with } \\
\text { repetitive duty in a fixed domain } \\
\text { will be mechanized. Placing a } \\
\text { greater demand for analytical } \\
\text { abilities in new recruits, thus } \\
\text { strengthening augmentation } \\
\text { between humans and technology. }\end{array}$ \\
\hline $\begin{array}{l}\text { Atkin, et } \\
\text { al. (2017) }\end{array}$ & $\begin{array}{l}\text { To examine the present } \\
\text { discuss management to } \\
\text { know the sector AI } \\
\text { discipline will worst hit }\end{array}$ & $\begin{array}{l}\text { Secondary } \\
\text { data } \\
\text { analysis }\end{array}$ & $\begin{array}{l}\text { AI will give top management } \\
\text { recommendations to base a } \\
\text { decision. AI will cause middle } \\
\text { managers to be bypassed, as } \\
\text { mission-critical decisions are } \\
\text { arrived at in a fraction of the time it } \\
\text { human managers' takes. }\end{array}$ \\
\hline $\begin{array}{l}\text { Chelliah } \\
\text { (2017) }\end{array}$ & $\begin{array}{l}\text { To enumerate the risks } \\
\text { which the white-collar } \\
\text { workers face from } \\
\text { advances in artificial } \\
\text { intelligence }(\mathrm{AI}) \text {. }\end{array}$ & $\begin{array}{l}\text { Expert } \\
\text { view and } \\
\text { Secondary } \\
\text { data } \\
\text { analysis }\end{array}$ & $\begin{array}{l}\text { There is high susceptibility of } \\
\text { white-collar jobs to AI; HR } \\
\text { practitioners need to envisage the } \\
\text { effect of AI on their firm. HR } \\
\text { departments needs to undergo } \\
\text { variations as some functions of HR } \\
\text { will be performed by AI }\end{array}$ \\
\hline $\begin{array}{l}\text { Goodson } \\
(2018)\end{array}$ & $\begin{array}{l}\text { To identify the main } \\
\text { point and action in issue } \\
\text { of Leadership and } \\
\text { Strategy }\end{array}$ & $\begin{array}{l}\text { Quantitati } \\
\text { ve Survey }\end{array}$ & $\begin{array}{l}\text { Firms will need to reinvent HR into } \\
\text { to fully realize the advantages, } \\
\text { Human Resources needs to become } \\
\text { Human AI Resources }\end{array}$ \\
\hline $\begin{array}{l}\text { Sion and } \\
\text { Gratiela } \\
(2018)\end{array}$ & $\begin{array}{l}\text { To determine whether } \\
\text { cognitively } \\
\text { machines will improve } \\
\text { and eliminate human } \\
\text { task. }\end{array}$ & $\begin{array}{l}\text { Secondary } \\
\text { data } \\
\text { analysis }\end{array}$ & $\begin{array}{l}\text { Numerous task needs employees } \\
\text { to operate with machines with task } \\
\text { transferred to machines. With } \\
\text { innovative goods, a growing } \\
\text { degree of automation is possible, } \\
\text { hence; mass automation. }\end{array}$ \\
\hline
\end{tabular}

Source: Field Survey, 2020

\section{CONCLUSION AND RECOMMENDATION}

A look at history shows that the greatest changes in human existence are consequence on developments in technology. Professions also feel the impact. Huginn, et al., (2019) opined that while some professions were lost there was an increased employment of artisans, and craftsmen in factories. At the present, the times are exceptional. Technological transformation is manifested in basically all area of our livings. Today, a lot of discussion and concerns has emerged following the jobs at the risk of exposure to technological development, including AI consequence on the increased use of automation will surged. For instance, $90 \%$ of the task performed by technical and the specialized employees are deemed to be moderately likely to be substituted (Huginn, et al., 2019). 
For this reason, there is the need to understand the effects of Artificial Intelligence on management. Is there knowledge about the effects of Artificial Intelligence on management? What is the current prediction for the future of management as it relate to emergence of Artificial Intelligence. The current study adopted the systematic literature review approach. Relevant literatures are selected and used for the analysis and analysis done following Jesson, Matheson \& Lacey (2011) six approach and steps as follows (a) Mapping the area through a scoping review, b) Detailed domain search, c) Quality appraisal, d) Data gathering e) Synthesis, and f) Report writing. The analysis shows that:

$\mathrm{AI}$ is a necessary evil to and for the future of firms. It will have varying degrees of effect on different areas of managerial work, including accounting, fraud detection, asset management, financial management, information management, marketing, inventory management, and human resource management, sales management, reputation risk management, quality management, production management, performance management, project management and network management. The implication for managerial role is that, AI technology will discharge managerial assignment and will be helpful in addressing management challenges. Managers therefore need get new competencies and skills to tap into new frontiers that are AI based.

\section{REFERENCE}

Antonescu, M. (2018). Are business leaders prepared to handle the upcoming revolution in business artificial intelligence? Acces la success acces la success. Calitatea, 19, 15- 19. Retrieved from https:/ / search.proquest.com/docview/2113235857?accountid=27513

Ateniese, G. (2019). Artificial intelligence gets real: What it is, where it's headed - and how Stevens is using it to make life healthier, safer and more secure. The Stevens Indicator, 140(1), 14-19. Retrieved July 12, 2019, from https://www.stevens.edu/sites/stevens edu/files/Indicator WEB Winter18 19.pdf

Atkin, B., \& Bildsten, L. (2017). A future for facility management. Construction Innovation, 17(2), 116124. doi: 10.1108/CI-11-2016-0059 Baldur Arnarsson. (2017, September 11). Gervigreind fækkar bankafólki. Morgunblaðið. Retrieved June 28, 2019, from https://www.mbl.is/frettir/innlent/2017/09/11/gervigreind_faekkar_bankafolki/

Barnard, C. L. (1973). The Functions of the Executive. London: Oxford University Press. Becker, M., \& Buchkremer, R. (2018). Ranking of current information technologies by risk and regulatory compliance officers at financial institutions - a German perspective. The Review of Finance and Banking, 10(1) Retrieved from https://search.proquest.com/docview/2208135738?accountid $=27513$

Bloem J, Van Doorn M, Duivestein S, Excoffier D, Maas R, Van Ommeren E (2014) The Fourth Industrial Revolution. Things Tighten.

Britton, B. L., \& Atkinson, D. G. (2017). An investigation into the significant impacts of automation in asset management. Journal of Economic and Social Development, 4(1), 2-14. Retrieved from https:// search.proquest.com/docview /1882363628? accountid=27513

Calvin, J. R., Beale, R. L., \& Moore, K. (2017). Acculturation and allied contribution and allied contributing factors that further advance cross-cultural management in learning and education: A conceptual approach. Journal of Organizational Culture, Communications and Conflict, 21(2), 1-11. Retrieved from https://search.proquest.com/docview/2023975283?accountid=27513

Cancialosi, C. (2016, April 11). Stuck in the middle with you: A survival guide for middle managers (and the zombie apocalypse). Forbes. Retrieved July 7, 2019, from 
https://www.forbes.com/sites/chriscancialosi/2016/04/11/a-survival-guide-formiddlemanagers-and-the-zombie-apocalypse/\#abd3fad3e5ff

Carr, H. H., \& Hogue, J. T. (1989). It takes A champion. Journal of Systems Management, 40(8), 15. Retrieved from https://search.proquest.com/docview/199809059?accountid=27513

Chelliah, J. (2017). Will artificial intelligence usurp white collar jobs? Human Resource Management International Digest, 25(3), 1-3. doi: 10.1108/HRMID-11-2016-0152

Chopra, K. N. (2018). Overview and application of artificial intelligence concepts and some important coevolving modern issues on management of organization and commerce. Journal of Internet Banking and Commerce, 23(3), 1-22. Retrieved from https://search.proquest.com/docview/2216881012?accountid $=27513$

Columbus, L. (2018, January 12). 10 Charts That Will Change Your Perspective on Artificial Intelligence's Growth. Forbes. Retrieved July 15, 2019, from https://www.forbes.com/sites/louiscolumbus/2018/01/12/10-charts-that-willchange-yourperspective-on-artificial-intelligences-growth/\#7e24f8944758

Donepudi, P. K. (2014a). Technology Growth in Shipping Industry: An Overview. American Journal of Trade and Policy, 1(3), 137-142. https://doi.org/10.18034/ajtp.v1i3.503

Donepudi, P. K. (2014b). Voice Search Technology: An Overview. Engineering International, 2(2), 91-102. https://doi.org/10.18034/ei.v2i2.502

Donepudi, P. K. (2017). Machine Learning and Artificial Intelligence in Banking. Engineering International, 5(2), 83-86. https://doi.org/10.18034/ei.v5i2.490

Donepudi, P. K. (2018). Application of Artificial Intelligence in Automation Industry. Asian Journal of Applied Science and Engineering, 7(1), 7-20. http://doi.org/10.5281/zenodo.4146232

Farajpour, S., \& Zerehnazi, M. (2013). Defining the place of expert systems in the operation of organizations. Kuwait Chapter of the Arabian Journal of Business and Management Review, 2(5), 122-134. Retrieved from https:// search.proquest.com/docview/1416303353?accountid=27513

Foster, A. T. (1988). Artificial intelligence in project management: A publication of the American association of cost engineers a publication of the American association of cost engineers. Cost Engineering, 30(6), 21. Retrieved from https://search.proquest.com/docview/220438981? accountid $=27513$

Gerber, D. L. (1988). TOMORROWS ORGANIZATION. Journal of Systems Management, 39(1), 33. Retrieved from https://search.proquest.com/docview/199819764?accountid=27513

Ghiselli, E. E., \& Johnson, D. A. (1970). Need Satisfaction, Managerial Success, and Organizational Structure. Personnel Psychology, 23(4), 569-576. doi: 10.1111/j.1744-6570.1970.tb01373.x

Gillikin, J. (2019, January 25). Advantages \& Disadvantages of Divisional Organizational Structure. Chron. Retrvied July 10, 2019 from https://smallbusiness.chron.com/advantages-disadvantagesdivisionalorganizational-structure-611.html

Gísli Porsteinsson. (2017, March 14). Aukin sjálfvirkni. Eru vélmenni að taka yfir? Origo. Retrieved from https:// www.origo.is/um-origo/blogg/sifellt-fleiri-storf-verdasjalfvik-/

Gleeson, P. (2019, January 28). Advantages \& Disadvantages of Matrix Organizational Structures in Business Organizations. Chron. Retrieved July 10, 2019 from https://smallbusiness.chron.com/advantages-disadvantages-matrix-organizationalstructuresbusiness-organizations-26350.html

Goodson, L. (2018). Quick takes. Strategy \& Leadership, 46(1), 51-56. Retrieved from https:// search.proquest.com/docview/2001045007?accountid=27513 50 Grant, R.M. (2008). The 
Future of Management: Where is Gary Hamel Leading Us? Long Range Planning 41(5):469-482. doi: 10.1016/j.lrp.2008.06.003

Hamel, G. (2007). The Future of Management. Boston, Massachusetts: Harvard Business School Press. Hirsch, P. B. (2018). Tie me to the mast: Artificial intelligence \& reputation risk management. The Journal of Business Strategy, 39(1), 61-64. Retrieved from https://search.proquest.com/docview/1995197991? accountid=27513

Hollensbe, E., Wookey, C., Hickey, L., Nichols, V., \& George, G. (2014). Organizations with Purpose. The Academy of Management Journal, 57, 1227-1234. doi: 10.5465/amj.2014.4005

Huginn F. Porsteinsson, Guðmundur Jónnson, Ragnheildur H. Magnúsdóttir, Lilja Dögg Jónsdótir \&Kristinn R. Pórisson. (2019). A Report from Icelandic Prime minister's committee on Iceland and Fourth Industrial Revolution. Retrieved, June 15, 2019, from https:/ / www.stjornarradid.is/lisalib/getfile.aspx?itemid=03be6340-3bfc-11e9- 9436-005056bc4d74

Jesson, J. K., Matheson, L. \& Lacey, F. M. (2011). Doing Your Literature Review. Traditional and Systematic Techniques. London: SAGE Publications Ltd.

Jones, G.R. (2013). Organizational Theory, Design, and Change (7th edition). Harlow, England: Person Education Limited. Karen, S. J. (1991). The role of artificial intelligence in information retrieval. Journal of the American Society for Information Science (1986-1998), 42(8), 558. Retrieved from https://search.proquest.com/docview/216893532?accountid=27513

Kiron, D., \& Spindel, B. (2019). Rebooting work for a digital era. MIT Sloan Management Review, 60(3), 0_1,0_2,1-10. Retrieved from https:// search.proquest.com/docview $/ 2193094128$ ?accountid=27513

Klosters D (2016) World Economic Forum Annual Meeting 2016 Mastering the Fourth Industrial Revolution. World Economic Forum. http://www3.weforum.org/docs/Media/. Accessed 7 October 2018.

Klotz, F. (2016). Are you ready for robot colleagues? MIT Sloan Management Review, 58(1), 0. Retrieved from https:// search.proquest.com/docview/1832180555?accountid=27513

Ko, C. (2015). Integrating RFID, web-based technology, and artificial intelligence in engineering management. Scientia Iranica Transaction A, Civil Engineering, 22(2), 299-312. Retrieved from https://search.proquest.com/docview/1685874234?accountid=27513

Koch, F. L., \& Carlos, B. W. (2001). Decentralized network management using distributed artificial intelligence. Journal of Network and Systems Management, 9(4), 375. Retrieved from https://search.proquest.com/docview/201341854?accountid=27513

Kolbjørnsrud, V., Amico, R., Thomas, R. J. (2015). The promise of artificial intelligence: Redefining management in the workforce of the future. Accenture.

Kubheka, I., Kholopane, P., \& Mbohwa, C. (2013). The effects of flattening hierarchies on employee performance in organizations: A study of a South African retail group. International Conference on Law, Entrepreneurship and Industrial Engineering (ICLEIE'2013), April 15-16, 217-222. Johannesburg (South Africa). Retrieved from https://core.ac.uk/download/pdf/54187702.pdf

Manaila, I.F. (2019, February 26). The art of possible deep Learning use cases. Presentation at the meeting of IBM Montpelier, Europe. Marr, B. (2016, April 5). Why everyone must get ready for the 4th industrial revolution. Forbes. Retrieved June 28, 2019, from https://www.forbes.com/sites/bernardmarr/2016/04/05/why-everyone-must-getready-for-4thindustrial-revolution/\#26be9e2f3f90.

McCurry, J. (2017, January 5). Japanese company replaces office workers with artificial intelligence. The Guardian. Retrieved May 18, 2019, from https://www.theguardian.com/technology/2017/jan/05/japanese-companyreplaces-officeworkers-artificial-intelligence-ai-fukoku-mutual-life-insurance 
Meehan, L., C. (2019, February 12). Flat vs. Hierarchical organizational structure. Chron. Retrieved July 10, 2019 from https://smallbusiness.chron.com/flat-vs-hierarchicalorganizational-structure724.html

Mintzberg, H. (1973). The Nature of Managerial Work. NY: Harper \& Row.

Miyan, M. (2017). Applications of data mining in banking sector. International Journal of Advanced Research in Computer Science, 8(1) Retrieved from https://search.proquest.com/docview/1901446000?accountid=27513

Morgan, J. (2015, July 15). The 5 Types of Organizational Structures: Part 4, Flatarchies. Forbes. Retrieved July 10, 2019, from https://www.forbes.com/sites/jacobmorgan/2015/07/15/the-5-typesoforganizational-structures-part-4-flatarchies/\#6623036f6707

Moudud-Ul-Huq, S. (2014). The role of artificial intelligence in the development of accounting systems: A review. IUP Journal of Accounting Research \& Audit Practices, 13(2), 7-19. Retrieved from https://search.proquest.com/docview/1540398066?accountid=27513

Nwankwo, S., Obidigbo, B., \& Ekwulugo, F. (2002). Allying for quality excellence: Scope for expert systems in supplier quality management. The International Journal of Quality \& Reliability Management, 19(2), 187-205. Retrieved from https://search.proquest.com/docview/197617739?accountid=27513

Ómar Óskarsson. (2019, March 3). Líkur á að priðja hvert starf breytist. Morgunblaðið. Retrieved June 28, 2019 fromPark SC (2017) The Fourth Industrial Revolution and implications for innovative cluster policies. AI \& Society 33(3). pp 433-45.

Ouye, J.A. (2011). Five Trends that Are Dramatically Changing Work and Workplace. Knoll Workplace Research. Retrieved June 15, 2019, from https://www.knoll.com/document/1352940439324/WP_FiveTrends.pdf

Rezvani, Z. (2017). Who is a Middle Manager: A literature Review. Journal of Family Business Management. doi:10.15226/2577-7815/1/2/00104

Schwab K (2017) The fourth industrial revolution. Crown Business

Schwab, K. (2015, January 14). The Fourth Industrial Revolution: what it means, how to respond. World Economic Forum. Retrieved June 25, 2019, from https://www.weforum.org/agenda/2016/01/thefourth-industrial-revolution-whatit-means-and-how-to-respond/

Shim, J. K., \& Rice, J. S. (1988). Expert systems applications to managerial accounting. Journal of Systems $\begin{array}{llll}\text { Management, } & \text { 39(6), } & \text { Retrieved }\end{array}$ https://search.proquest.com/docview/199850554?accountid=27513

Sion, G. (2018). How artificial intelligence is transforming the economy. will cognitively enhanced machines decrease and eliminate tasks from human workers through automation? Journal of SelfGovernance and Management Economics, 6(4), 31. doi: 10.22381/JSME6420185

Sólveig Klara Ragnarsdóttir. (2019, September 19). Fimm millistjórnendum hjá sýn sagt upp störfum. RÚV. Retrieved from https://www.ruv.is/frett/fimm-millistjornendumhja-syn-sagt-uppstorfum?fbclid=IwAR3tWol8Poto2XSAnY n0fTYxml4Z0y fqfCWKeBbshzNOAVcvADkIU4Yo

Sreedevi, E., Saravanan, K., \& Subhamathi, V. (2017). A REVIEW OF ARTIFICIAL INTELLIGENCE SYSTEMS. International Journal of Advanced Research in Computer Science, 8(9) Retrieved from https://search.proquest.com/docview/1980479933?accountid=27513

Syam, N., \& Sharma, A. (2018). Waiting for a sales renaissance in the fourth industrial revolution: Machine learning and artificial intelligence in sales research and practice. Industrial Marketing Management, 69, 135-146. doi: 10.1016/j.indmarman.2017.12.019 The 4 industrial revolutions. (2017, February 23). Retrieved June 25, 2019, from https://www.sentryo.net/the-4-industrialrevolutions/ 
Tranfield, D., Denyer, D., \& Smart, P. (2003). Towards a Methodology for Developing Evidence-Informed Management Knowledge by Means of Systematic Review [PDF Digital Edition]. British Journal of Management, 14, 202-222.

Wahl, D.C. (2019, January 9). We live in extraordinary times. A Medium Corporation. Retrieved June 25, 2019, from https://medium.com/age-of-awareness/we-live-inextraordinary-times-b4aaf2ed8176 